\title{
Anti-ulcerogenic effect of osajin on indomethacin-induced gastric damage in rats
}

\author{
Huseyin Serkan Erol ${ }^{1}$, Ahmet Cakir ${ }^{2}$, Murat Koc ${ }^{3}$, Serkan Yildirim ${ }^{4}$, Mesut Halici ${ }^{5}$ \\ ${ }^{1}$ Kastamonu University, Faculty of Veterinary Medicine, Department of Biochemistry, Kastamonu, Turkey \\ ${ }^{2}$ Kilis 7 Aralik University, Faculty of Science and Art, Department of Chemistry, Kilis, Turkey \\ ${ }^{3}$ Ankara Yildirim Beyazit University, Public Health Institute, Department of Traditional, Complementary \\ and Integrative Medicine, Ankara, Turkey \\ ${ }^{4}$ Ataturk University, Faculty of Veterinary Medicine, Department of Pathology, Erzurum, Turkey \\ ${ }^{5}$ Ataturk University, Faculty of Veterinary Medicine, Department of Biochemistry, Erzurum, Turkey
}

Received December 2, 2019

Accepted December 21, 2020

\begin{abstract}
Ulcer is the most common undesirable result of using non-steroid anti-inflammatory drugs such as indomethacin. In the present study, osajin was experimentally used on indomethacin-induced gastric ulcer in rats. Osajin was purified from Maclura pomifera (Raf.) C. K. Schneid fruits by using the chromatographic methods. Thirty six rats were divided into six groups as follows: healthy (control), IND (indomethacin), RAN (ranitidine, $25 \mathrm{mg} / \mathrm{kg}$ ), OSJ 100 (osajin, $100 \mathrm{mg} / \mathrm{kg}$ ), OSJ $200(200 \mathrm{mg} / \mathrm{kg}$ ) and OSJ 400 (osajin, $400 \mathrm{mg} / \mathrm{kg}$ ). Following a 24-h fasting, IND was administered to the treatment groups at a dose of $25 \mathrm{mg} / \mathrm{kg}$. RAN and OSJ were given orally to rats following $5 \mathrm{~min}$ of IND administration. Then, gastric tissues were taken $6 \mathrm{~h}$ after the IND administration. Determination of the ulcer area, pathological evidence, and biochemical indices such as lipid peroxidation, superoxide dismutase, glutathione, and catalase were performed. IND generated diffuse ulcer areas, severe hyperaemia, oedema, necrotic epithelium, and mononuclear cell infiltration in the mucosa, and significantly increased lipid peroxidation while also decreasing the glutathione concentration, superoxide dismutase and catalase activities of the tissue. OSJ and RAN showed significant amelioration on ulcer area and biochemical indices. Therefore, OSJ may be potentially therapeutic for gastric ulcers.
\end{abstract}

Ranitidine, gastric ulcer, Maclura pomifera

Ulcer is a limited or widespread mucosal necrotic wound that can bleed and involve all the tissue layers as a consequence of damage to the protective structure of the gastrointestinal (GI) tracts of mammals (Laine 2016). The most common causes of a GI ulcer in mammals are Helicobacter pylori, drugs, alcohol, and stress conditions such as cold or hot temperatures.

Non-steroidal anti-inflammatory drugs (NSAIDs) have been reported to be the most important cause of GI ulcers after H. pylori (Bayir et al. 2006). Across the world, NSAIDs such as aspirin, ibuprofen, and indomethacin are frequently used as medication for inflammation, pain and rheumatoid arthritis both in human and animal patients. The NSAIDs produce their curative effects via the inhibition on COX (cyclooxygenase) enzyme activity in cells. However, the inhibition of the COX system, which is related to arachidonic acid, causes reduced prostaglandin $\mathrm{E}_{2}\left(\mathrm{PGE}_{2}\right)$ synthesis that is part of the GI protective system (Rainsford 1988).

In recent studies, reactive oxygen species (ROS) have been shown to be an important factor in the pathophysiology of GI ulcers (Atalay et al. 2015; Bozkurt et al. 2017), inducing oxidative stress in cells (Pandir et al. 2019). It has been reported that the ROS generate oxidized products via attacking the phospholipids of the cell membrane. They also increase the tissue damage by causing deterioration in the structure of enzymes, proteins, and receptors (Slater et al. 1987).

Address for correspondence:

Huseyin Serkan Erol

Department of Biochemistry

Faculty of Veterinary Medicine, Kastamonu University

Kastamonu, 37200, TURKEY

Phone: +90 3662805116

E-mail: hserol@kastamonu.edu.tr

http://actavet.vfu.cz/ 
Osajin (OSJ) is classified in the isoflavone group and has significant pharmacological effects on various disease models in animals. Previous studies reported that OSJ has potential curative effects on the heart (Florian et al. 2006), kidney (Bartošíková et al. 2006) and ovarian (Cigsar et al. 2015) ischaemia/reperfusion models, showing strong antioxidant properties in these studies. Although OSJ has previously been reported to have some properties such as inhibition of COX-2 expression in skin cell (Kim et al. 2017) and DNA protectivity (Diopan et al. 2008), its effect on the GI system has not been investigated. Therefore, the anti-ulcerogenic effects of OSJ purified from Maclura pomifera (Raf.) C. K. Schneid fruits on the indomethacin-induced gastric damage in rats were investigated by performing macroscopic, histopathologic and biochemical examinations.

\section{Materials and Methods}

All the reagents of the study were provided from Sigma-Aldrich, Illinois, USA.

Purification of osajin

The Maclura pomifera (Raf.) C. K. Schneid (osage orange) fruits were collected from the Ankara University (Ankara, Turkey) campus area in November. The identification and verification of fruits were performed by Dr. Murat Koc. Some of the samples (case code: M. Koc 1292) are stored at the Biology Department Herbarium of the Bozok University (Yozgat, Turkey).

In the present study, OSJ was purified from the fruits by using some chromatographic methods. The dried fruits were ground by a mill and then extracted with ethyl acetate $5 \times$ under room conditions. The extract $(114$ g) was acquired at the end of extraction, weighed $25 \mathrm{~g}$, then fractioned by silica gel column chromatography. At the end of the chromatographic processes, two major materials (approximately $5 \mathrm{~g}$ ) were obtained and named as the MP-1 and MP-2 after collecting. The chemical structure was confirmed by using the spectroscopic methods which were UV (ultraviolet)-visible, IR (infrared), ${ }^{1} \mathrm{H}-\mathrm{NMR}$ (proton-nuclear magnetic resonance), ${ }^{13} \mathrm{C}-\mathrm{NMR}$ $\left({ }^{13}\right.$ carbon-nuclear magnetic resonance), 1D and 2D NMR (1 and 2 dimensions nuclear magnetic resonance) after the purification.

Characterization of 9-hydroxy-7-(p-hydroxyphenyl)-2,2-dimethyl-10-(3-methyl-2-butenyl)1,5-dioxane-2H-phenanthrene-8-one (osajin)

$\operatorname{IR}\left(\mathrm{KBr}, v, \mathrm{~cm}^{-1}\right) 3437,3229,2980,2932,2128,1651,1568,1434,1205,1074 .{ }^{1} \mathrm{H}-\mathrm{NMR}\left(400 \mathrm{MHz}, \mathrm{CDCl}_{3} \delta, \mathrm{ppm}\right)$ $1.51\left(6 \mathrm{H}, \mathrm{s}, \mathrm{CH}_{3}\right), 1.71\left(3 \mathrm{H}, \mathrm{s}, \mathrm{CH}_{3}\right), 1.80\left(3 \mathrm{H}, \mathrm{s}, \mathrm{CH}_{3}\right), 3.40\left(2 \mathrm{H}, \mathrm{d}, J=7.3 \mathrm{~Hz}, \mathrm{CH}_{2}\right), 5.20(1 \mathrm{H}, \mathrm{d} J=7.3 \mathrm{~Hz}$, $\mathrm{C}=\mathrm{CH}), 5.58-5.68(1 \mathrm{H}, \mathrm{m}, \mathrm{C}=\mathrm{CH}), 6.68-6.76(1 \mathrm{H}, \mathrm{m}, \mathrm{C}=\mathrm{CH}), 6.78-6.83(2 \mathrm{H}, \mathrm{m}, \mathrm{PhH}), 7.26-7.35(2 \mathrm{H}, \mathrm{m}, \mathrm{Hz}$, $\mathrm{PhH}), 7.88(1 \mathrm{H}, \mathrm{d}, \mathrm{C}=\mathrm{CH}), 13.03(1 \mathrm{H}, \mathrm{s}, \mathrm{OH}), 13.07(1 \mathrm{H}, \mathrm{s}, \mathrm{OH}) .{ }^{13} \mathrm{C}-\mathrm{NMR}\left(100 \mathrm{MHz}, \mathrm{CDCl}_{3} \delta, \mathrm{ppm}\right) 18.0$, $21.5,25.0,28.5,77.7,100.8,105.7,107.7,115.0,115.8,121.9,123.4,123.7,128.2,130.4,131.8,152.8,154.8$, 156.2, 157.1, 159.3, 181.5.) $\left(\mathrm{C}_{25} \mathrm{H}_{24} \mathrm{O}_{5} ; \mathrm{MA}: 404 \mathrm{~g} / \mathrm{mol}\right)$ (Fig. 1)

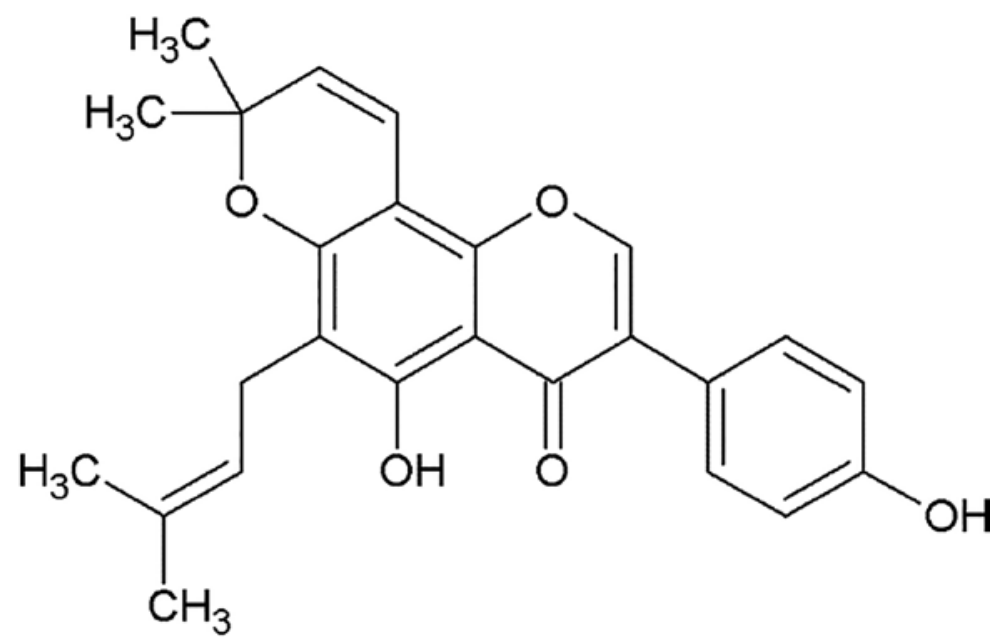

Fig. 1. The molecular structure of osajin 
Animal model of gastric injury

Necessary permission was obtained by the decision no. 36643897-118 from Ataturk University Local Ethics Committee for Animal Experiments. Thirty-six male Sprague Dawley rats (about 4 months old and 180-200 g weight) were selected and kept under normal conditions (ad libitum water and feed, $12 / 12 \mathrm{~h}$ light cycle, $24{ }^{\circ} \mathrm{C}$ room temperature, $60 \%$ humidity) for a week before the study. One day before the start of the study, chow pellets were taken away from all groups and the floor of cages was cleaned for $6 \mathrm{~h}$ to avoid coprophagic behaviour of rats.

The rats were homogeneously divided into six groups $(n=6)$ designated as healthy, IND, RAN, OSJ 100, OSJ 200, and OSJ 400. Indomethacin (IND) (Endol ${ }^{\circledR}$, Deva Ilac San., Tekirdag, Turkey), ranitidine (RAN) (Ulcuran ${ }^{\circledR}$, Yavuz

Table 1. The experimental design.

\begin{tabular}{lcll}
\hline Groups & Treatments & \\
\hline Healthy control & $1 \mathrm{ml}$ & distilled water \\
IND & $25 \mathrm{mg} / \mathrm{kg}$ & indomethacin (per os) \\
RAN & $25 \mathrm{mg} / \mathrm{kg}$ & ranitidine & $+25 \mathrm{mg} / \mathrm{kg}$ indomethacin (per os) \\
OSJ 100 & $100 \mathrm{mg} / \mathrm{kg}$ & osajin & $+25 \mathrm{mg} / \mathrm{kg}$ indomethacin (per os) \\
OSJ 200 & $200 \mathrm{mg} / \mathrm{kg}$ & osajin & $+25 \mathrm{mg} / \mathrm{kg}$ indomethacin (per os) \\
OSJ 400 & $400 \mathrm{mg} / \mathrm{kg}$ & osajin & $+25 \mathrm{mg} / \mathrm{kg}$ indomethacin (per os) \\
\hline
\end{tabular}

IND - indomethacin, RAN - ranitidine, OSJ - osajin Ilac San., Istanbul, Turkey) and OSJ were prepared as a suspension in distilled water. The solutions $(1 \mathrm{ml}$ for each rat) were administered orally by using a steel gavage needle (G 18, FST, California, USA) to treatment groups after $5 \mathrm{~min}$ from IND administration at a dose of $25 \mathrm{mg} / \mathrm{kg}$. RAN was used as a reference drug for comparing the effects of OSJ on the gastric injury and the dose of RAN was determined according to Odabasoglu et al. (2008). The experimental procedure is summarized in Table 1.

The rats were euthanized under a high dose of ketamine (Alfasan, Woerden, Netherland) $(75 \mathrm{mg} / \mathrm{kg}$ ) anaesthesia using the cervical dislocation method after $6 \mathrm{~h}$ from IND administration. The rat stomach was incised from the pylori to the duodenum on curvatura majoris by using surgical scissors. Tissue sample was carefully washed by saline. Then, the stomach was stretched and pinned on a polystyrene foam board for a photograph to be taken and for the ulcer area to be estimated using a graph paper. Tissue samples were fixed in a $10 \%$ formalin solution in sterile Petri plates for biochemical assays. The Petri plates were stored at $-80^{\circ} \mathrm{C}$ till the experimental day.

\section{Macroscopic examination}

The stomach tissues were examined for determining the ulcer areas by using a transparent millimetric graph paper and a magnifier. Ulcer areas on the whole mucosal area were marked by using a permanent marker on the millimetric transparent graph paper. These areas were expressed as $\mathrm{mm}^{2}$.

\section{Microscopic examination}

The stomach tissue was fixed in a $10 \%$ formalin solution for $48 \mathrm{~h}$ to evaluate the histopathological examination. The sample was embedded in paraffin after the routine tissue tracking process. Sections at a thickness of about $4 \mu \mathrm{m}$ were cut from the paraffin-embedded samples. Prepared slides were stained with haematoxylin and eosin dyes and examined by using a light microscope (Leica DM 1000, Germany). The sections were evaluated as none $(-)$, mild $(+)$, moderate $(++)$ and severe $(+++)$ by following the histopathological findings.

Preparing the tissue homogenates

The tissue samples were pulverized by using liquid nitrogen and a porcelain mortar. They were weighed at $25 \mathrm{mg}$ into the sterile Eppendorf tubes. Then, $1.5 \mathrm{ml}$ homogenate buffer (for lipid peroxidation level: $10 \% \mathrm{KCl}$, for superoxide dismutase activity: $0.2 \mathrm{mM}$ Tris- $\mathrm{HCl}$ at $\mathrm{pH}$ 7.4, for glutathione concentration: $50 \mathrm{mM}$ Tris- $\mathrm{HCl}$ at $\mathrm{pH}$ 7.4, for catalase activity: $50 \mathrm{mM} \mathrm{KH}_{2} \mathrm{PO}_{4}$ at $\mathrm{pH}$ 7) was added into the tubes. The tubes were homogenized by using a tissue homogenizer (Tissulyser II, Qiagen, Hilden, Germany) at $35 \mathrm{~Hz}$ for one minute. All homogenates were filtered and centrifuged (320R, Hettich, Tuttlingen, Germany) according to the experimental procedures that stated the appropriate $g$ and time for each parameter. The supernatants were collected from homogenate tubes after the centrifugation process.

\section{Determination of lipid peroxidation level}

For the determination of lipid peroxidation (LPO) levels of tissues, a method based on the reaction between malondialdehyde (MDA) and thiobarbituric acid was performed as described by Ohkawa et al. (1979). The results were calculated by utilizing the standard graph generated by using tetraethoxypropane and expressed as $\mathrm{nmol} / \mathrm{g}$ tissue.

\section{Determination of superoxide dismutase activity}

The method described by Sun et al. (1988) was used for determining the superoxide dismutase (SOD) activity of the tissue. Samples were read at $560 \mathrm{~nm}$ by using a spectrophotometer, then the results were expressed as $\mathrm{mmol} / \mathrm{min} / \mathrm{mg}$ tissue. 
Determination of the glutathione concentration

The method based on the reaction between DTNB (5,5'-dithiobis-[2-nitrobenzoic acid]) and the sulphhydryl group of glutathione was used for measuring the amount of total glutathione (GSH) (Sedlak and Lindsay 1968). The results are expressed as $\mathrm{nmol} / \mathrm{mg}$ tissue.

Determination of catalase activity

The method described by Aebi (1984) was used for determining the catalase (CAT) activity by reading the decomposition of $\mathrm{H}_{2} \mathrm{O}_{2}$ at $240 \mathrm{~nm}$. The acquired results are described as $\mu \mathrm{mol} / \mathrm{min} / \mathrm{mg}$ tissue.

Statistical analysis

All statistical analyses were performed using the IBM SPSS 20.0 software. The statistical differences and significances in the results were determined via ANOVA (One-way Analysis of Variance) test and differences at $P<0.05$ were defined as significant. Duncan's test was used for multiple comparisons of the results. Semi-objective results in histopathological findings were analysed by using non-parametric Kruskal-Wallis test and Mann Whitney U test for paired comparisons.

\section{Results}

\section{Macroscopic examination}

The macroscopic views of stomach ulcer areas are shown in Fig. 2 (Plate VI). Measured ulcer areas shown in Fig. 3 were significantly increased in the indomethacin (IND) administered groups $(P<0.05)$. OSJ and RAN administrations markedly decreased the ulcer areas compared to the IND group $(P<0.05)$. There was no significant difference between the RAN and OSJ 100 groups $(P>0.05)$, and between the healthy and OSJ 400 groups $(P>0.05)$.

\section{Ulcer Areas}

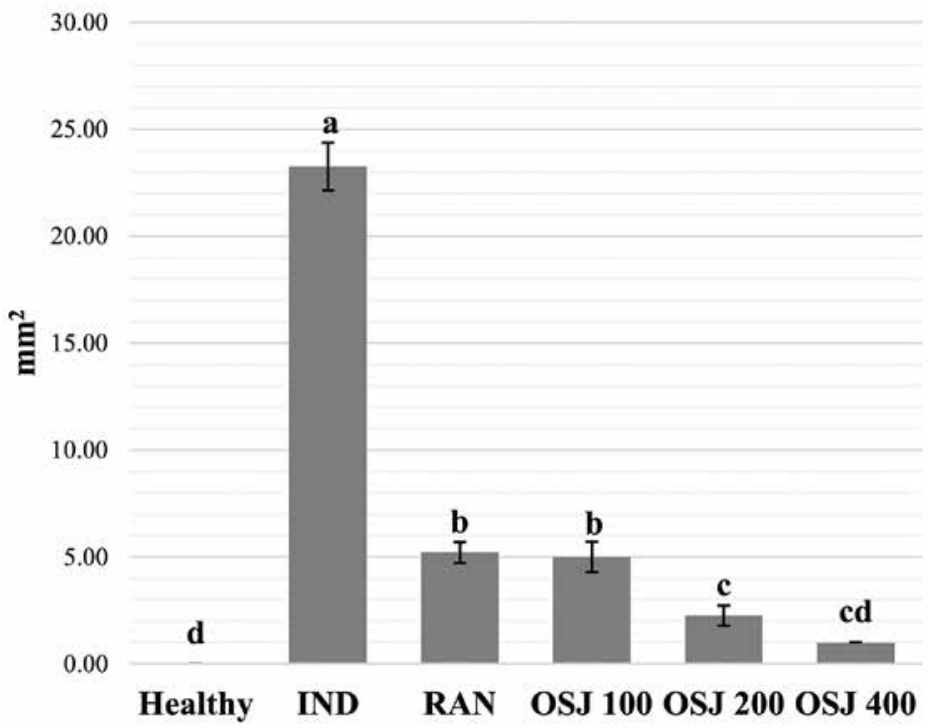

Fig. 3. Results of the ulcer area measurement

IND - indomethacin, RAN - ranitidine, OSJ - osajin. The different letter in each figure indicates significant differences between the groups $(P<0.05)$. The same letter in each figure indicates similarity between the groups $(P>0.05)$. 


\section{Microscopic examination}

Normal histological structure was observed in the healthy control group (Plate VII, Fig. 4a). Severe haemorrhagic necrotic gastritis was determined in the mucosa of the IND group. Severe focal haemorrhages, necrotic epithelial cells reached up to lamina muscularis, mild mononuclear cell infiltration and hyperaemia in vessels were observed in the IND group (Plate VII, Fig. 4b). Also, severe oedema, hyperaemia in vessels of submucosa and lamina muscularis were determined.

In the RAN group, mild degeneration in the mucosa and mild hyperaemia in vessels of the mucosa, lamina muscularis, and sub-mucosa were determined (Plate VII, Fig. 4c).

Severe haemorrhage in the mucosa, severe necrosis in mucosa epithelium, severe hyperaemia in vessels and mild mononuclear cell infiltration around necrotic cells were observed in OSJ 100 group. In sub-mucosa, severe oedema, hyperaemia in vessels and mild mononuclear cell infiltration were determined. Furthermore, hyperaemic vessels were observed in the lamina muscularis (Plate VII, Fig. 4d).

In the OSJ 200 group, moderate haemorrhagic necrotic gastritis was observed. In the mucosa, moderate haemorrhagic necrotic epithelium, mild mononuclear cell infiltration and hyperaemia in the mucosa, lamina muscularis and submucosa were indicated (Plate VII, Fig. 4e).

Hyperaemia was observed in the mucosa, submucosa, and lamina muscularis of the OSJ 400 group (Plate VII, Fig. 4f). Moderate oedema in the submucosa was determined. The histopathological findings of all groups are summarized in Table 2.

Table 2. Summarized histopathological findings of stomach tissues.

\begin{tabular}{|c|c|c|c|c|c|}
\hline & $\begin{array}{l}\text { Hyperaemia } \\
\text { in mucosa }\end{array}$ & $\begin{array}{c}\text { Necrotic } \\
\text { epithelium in mucosa }\end{array}$ & $\begin{array}{l}\text { Mononuclear cell } \\
\text { infiltration }\end{array}$ & $\begin{array}{l}\text { Hyperaemia } \\
\text { in vessels }\end{array}$ & $\begin{array}{l}\text { Oedema } \\
\text { in mucosa }\end{array}$ \\
\hline Healthy & - & - & - & - & - \\
\hline IND & +++ & +++ & +++ & +++ & +++ \\
\hline RAN & + & + & + & + & ++ \\
\hline OSJ 100 & +++ & ++ & ++ & +++ & +++ \\
\hline OSJ 200 & ++ & ++ & ++ & +++ & ++ \\
\hline OSJ 400 & + & - & + & ++ & + \\
\hline
\end{tabular}

The lipid peroxidation level in the mucosa

The LPO level was used as an oxidative damage indicator of the tissue and expressed in Fig. 5A. IND caused significant increases in LPO levels of the IND, RAN and OSJ groups compared to the control group $(P<0.05)$. RAN and OSJ decreased the LPO level of tissues compared to the IND group $(P<0.05)$. Compared to the IND group, though OSJ at a 100 $\mathrm{mg} / \mathrm{kg}$ dose significantly decreased the LPO level $(P<0.05)$, the decrease in the LPO level was similar to the RAN group $(P>0.05)$.

The superoxide dismutase activity in the mucosa

The SOD activity of the stomach tissue is shown in Fig. 5B. IND significantly decreased the activity compared to the control group $(P<0.05)$. RAN and OSJ markedly increased the SOD activity $(P<0.05)$ compared to the IND group. There was no significant difference between SOD activities of the OSJ 100 and RAN groups $(P>0.05)$. 
A LPO Levels of Stomach Tissues

60.00

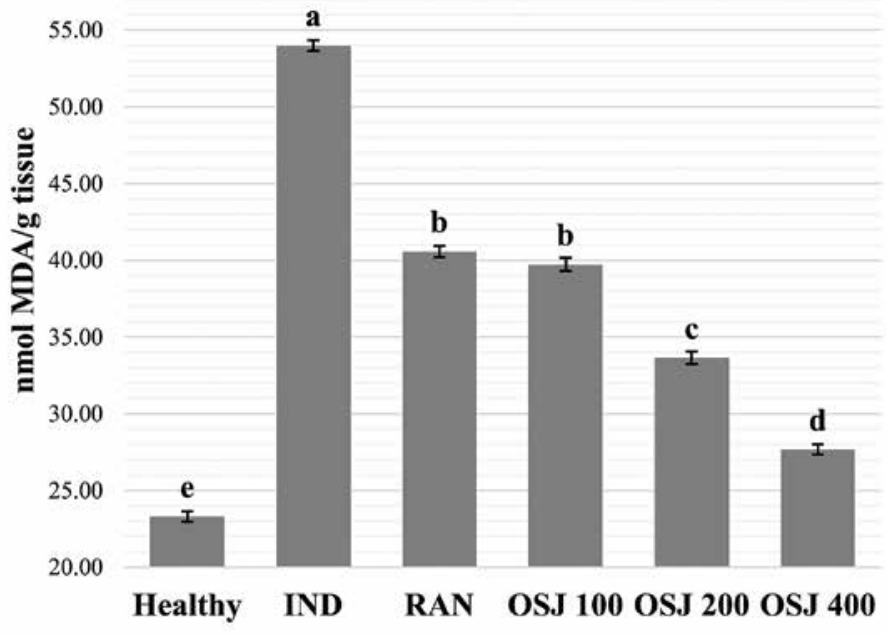

B SOD Activity of Stomach

Tissues

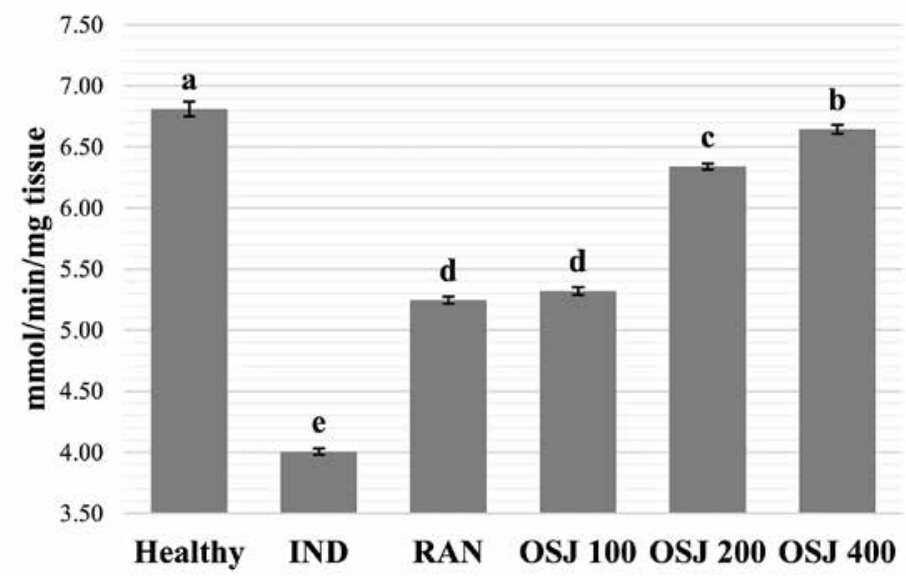




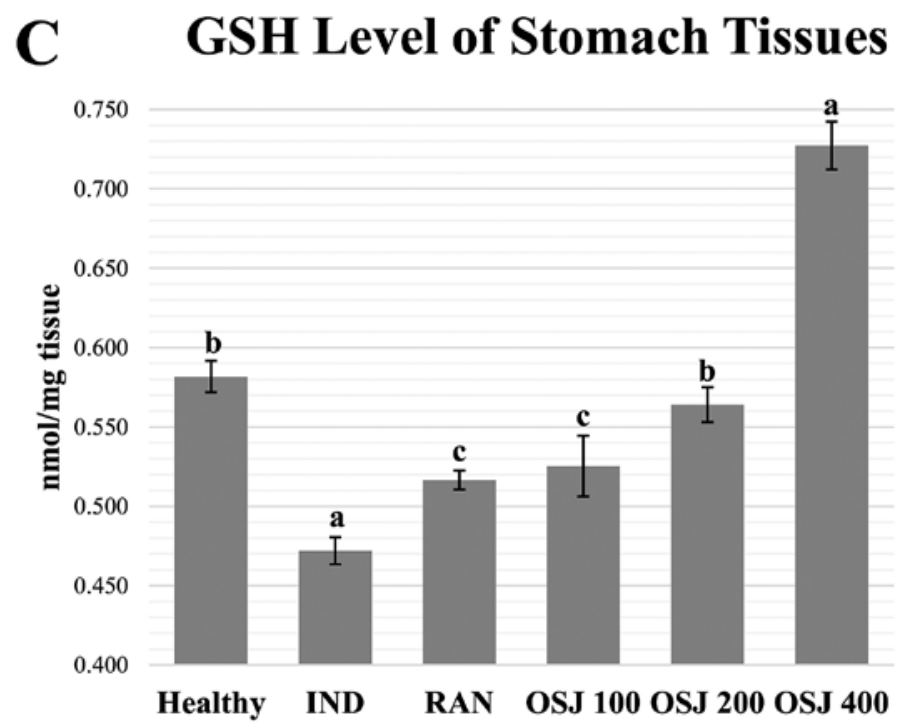

\section{CAT Activity of Stomach Tissues}

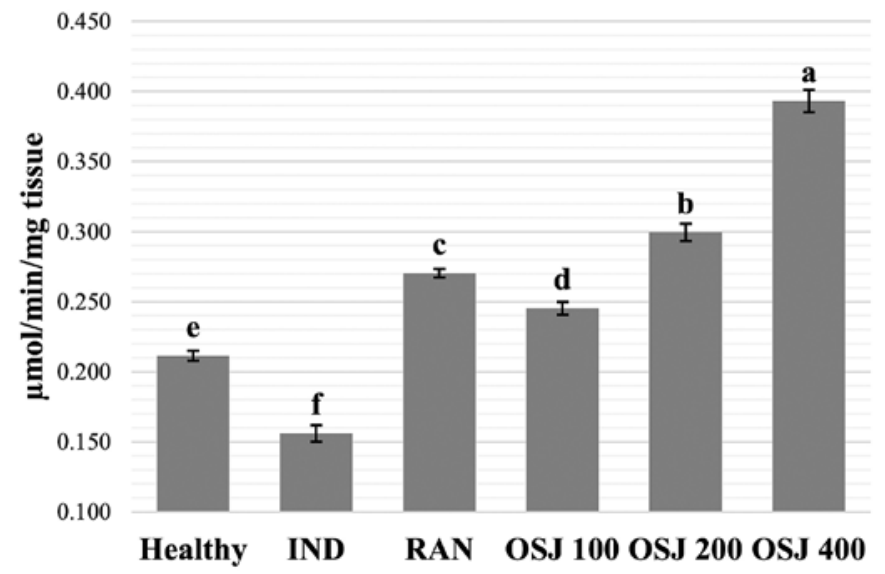

Fig. 5. The antioxidant status in the stomach tissues. A: the LPO levels in the stomach tissues; B: the SOD activities in the stomach tissues; C: the GSH levels in the stomach tissues; D: the CAT activities in the stomach tissues. IND - indomethacin, RAN - ranitidine, OSJ - osajin. The different letter in each figure indicates significant differences between the groups $(P<0.05)$. The same letter in each figure indicates similarity between the groups $(P>0.05)$. 
The GSH level in the mucosa

The GSH level of the tissues shown in Fig. 5C were decreased by IND compared to the control group $(P<0.05)$. RAN and OSJ significantly increased GSH levels compared to the IND group $(P<0.05)$. There was no significant difference between the OSJ 100 and RAN groups $(P>0.05)$, and between the control and OSJ 200 groups $(P>0.05)$. The GSH level of the OSJ 400 group was found to be markedly higher than in the control group $(P<0.05)$.

\section{The catalase activity in the mucosa}

The CAT activity of tissues, shown in Fig. 5.D, was significantly decreased by IND compared to the control group $(P<0.05)$. RAN and OSJ markedly increased the activity compared to IND $(P<0.05)$.

\section{Discussion}

The increased use of painkillers worldwide is the second major cause of the ulcers following H. pylori (Conaghan 2012). The effects of NSAIDs on the gastric mucosa originate both directly via their chemical properties and indirectly via inhibition of COX enzymes. The NSAIDs inhibit the production of prostaglandins formed by the COX in the gastric mucosa, and histamine that regulates the release of the protective mucus. Therefore, the gastric mucosa is damaged by gastric acid due to the thinning of the protective mucus layer, and then the irritation of mucosa triggers a severe inflammatory process in the gastric tissue (Halici et al. 2005). Moreover, the increase in the amount of ROS, which are also generated by the neutrophils in the mucosa, exacerbate the inflammatory process by inducing immune mediators such as TNF- $\alpha$ and IL-1 $\beta$ (Matsui et al. 2011; Musumba et al. 2009). The immune cells, particularly those that include the mononuclear cells, begin migrating into the gastric tissue after the activation of mediators ( $\mathrm{Jia}$ et al. 2007). The inflammatory response causes oedema, vascular haemorrhage, and bleeding by increasing the blood flow in the tissue. In the group given IND, mucosal haemorrhage, necrotic cells, mononuclear cell infiltration, hyperaemia in vessels and sub-mucosal oedema occurrences were all observed and similar pathological findings, particularly in the mucosa, have also been reported in previous studies (Abbas and Sakr 2013; Wang et al. 2014). According to the pathological results of the present study, RAN and OSJ decreased the severity of the pathological events depending on their doses. Previous studies on ischaemia models (kidney, ovary, and heart) reported that OSJ markedly reduced the severity of haemorrhages and tissue injury that occurred due to ischaemia (Bartošíková et al. 2006; Cigsar et al. 2015; Florian et al. 2006).

In addition, NSAIDs lead to excessive electron leakage from the mitochondria that produce the ROS and thus, they cause a variety of generates in the cell and mitochondrial membranes. Therefore, the amount of ROS increases, causing the activation of cell apoptosis triggered by caspases 3 and 9 (Matsui et al. 2011). Phospholipids, which constitute the cell membrane, are oxidized by increased ROS. This oxidation results in the formation of a malondialdehyde (MDA) structure, which is an important indicator of the tissue LPO level and cellular damage of tissue (Halici et al. 2005). In the present study, RAN and OSJ significantly decreased the LPO level of the tissues in a dose-dependent manner. In a previous study, an excessive increase in the amount of ROS was observed by administering the IND which induced a significant increase in the LPO level of the gastric tissue (Chattopadhyay et al. 2006).

In cells, SOD attempts to eliminate life-threatening ROS for cells by performing a dismutation reaction. SOD converts ROS to hydrogen peroxide, which is a less toxic structure for the cell life and membranes. OSJ increased the SOD activity in the gastric 
tissue, whereas IND considerably decreased the activity. Also, a significant increase in the ulcerated areas was observed in the groups where SOD activities were significantly decreased. Hence, it is thought that OSJ can defend the mucosa cells against ROS by providing an increase in the SOD activity. Besides, the ulcers formed by NSAIDs may be directly connected with the existence of ROS. Likewise, severe tissue injury in parallel with a significant decrease in the SOD activity by IND has been previously reported (Dengiz et al. 2007; Halici et al. 2005; Odabasoglu et al. 2006; Odabasoglu et al. 2008).

Another member of the antioxidant system that plays a role in the elimination of produced hydrogen peroxide as a consequence of the SOD activity is GSH, a tripeptide that includes cysteine. Hydrogen peroxide is converted to water by reducing GSH via glutathione peroxidase activity. In the present study, while a significant decrease in GSH level was determined in the IND group, the GSH level of the tissue markedly increased in the RAN and OSJ groups. According to the results, the decreased GSH level measured in tissues could be related to severe tissue damage that may have been caused by GSH consumed by ROS or by reduced antioxidant enzymes such as glutathione reductase or peroxidase. Similarly, previous studies on gastric injury in rats reported that the GSH level of tissue was significantly decreased by administering IND (Dengiz et al. 2007; Halici et al. 2011; Kaplan et al. 2012).

CAT, which is an important member of the antioxidants, converts hydrogen peroxide to water and oxygen. In the current study, the IND markedly decreased the CAT activity of stomach tissues. RAN and dose-dependent OSJ considerably increased the activity that was decreased by IND. Previous studies determined similar changes in the CAT activity in the gastric tissue (Morsy et al. 2010; Sivalingam et al. 2008).

In conclusion of our current study findings, OSJ significantly reduced the diffuse ulcerated area and supported the antioxidant system of the gastric tissue against the ROS that were generated by IND. Not only has IND become a major factor in GI ulcers by chemically creating ulcerative degeneration in the mucosa, but it also generates excessive oxidative stress in the stomach tissue. In the light of the present study, OSJ may be potentially therapeutic for gastric ulcers that are produced by NSAIDs such as indomethacin.

\section{Acknowledgements}

This work was supported by the Scientific Funds of the Ataturk University (BAP-2012/364). We would like to thank Yunus Akturk for his assistance in preparing the histopathological part of the study.

\section{References}

Abbas AM, Sakr HF 2013: Effect of selenium and grape seed extract on indomethacin-induced gastric ulcers in rats. J Physiol Biochem 69: 527-537

Aebi H 1984: Catalase in vitro. Methods Enzymol 105: 121-126

Atalay F, Odabasoglu F, Halici M, Cakir A, Cadirci E, Aslan A, Aydin Berktas O, Kazaz C 2015: Gastroprotective and antioxidant effects of Lobaria pulmonaria and its metabolite rhizonyl alcohol on indomethacin-induced gastric ulcer. Chem Biodivers 12: 1756-1767

Bartošíková L, Nečas J, Suchý V, Janoštíková E, Bartošík T, Juřica J, Florian T, Klusakova J, Frydrych M 2006 : Protective effects of osajin in ischemia-reperfusion of laboratory rat kidney. Pharmazie 61: 552-555

Bayir Y, Odabasoglu F, Cakir A, Aslan A, Suleyman H, Halici M, Kazaz C 2006: The inhibition of gastric mucosal lesion, oxidative stress and neutrophil-infiltration in rats by the lichen constituent diffractaic acid. Phytomedicine 13: 584-590

Bozkurt İ, Dilek E, Erol HS, Çakir A, Hamzaoğlu E, Koç M, Keleş ON, Halici MB 2017: Investigation on the effects of pomiferin from Maclura pomifera on indomethacin-induced gastric ulcer: An experimental study in rats. Med Chem Res 26: 2048-2056

Chattopadhyay I, Bandyopadhyay U, Biswas K, Maity P, Banerjee RK 2006: Indomethacin inactivates gastric peroxidase to induce reactive-oxygen-mediated gastric mucosal injury and curcumin protects it by preventing peroxidase inactivation and scavenging reactive oxygen. Free Radic Biol Med 40: 1397-1408

Cigsar G, Keles ON, Can S, Karaca M, Can I, Erol HS, Sagir D, Abuc OO, Cakir A, Sahin ZG, Unal B, Anil B, Halici MB 2015: The protective effects of osajin on ischemia/reperfusion injury to rat ovaries: biochemical and histopathological evaluation. Kafkas Univ Vet Fak Derg 21: 753-760 
Conaghan PG 2012: A turbulent decade for NSAIDs: update on current concepts of classification, epidemiology, comparative efficacy, and toxicity. Rheumatol Int 32: 1491-1502

Dengiz GO, Odabasoglu F, Halici Z, Suleyman H, Cadirci E, Bayir Y 2007: Gastroprotective and antioxidant effects of amiodarone on indomethacin-induced gastric ulcers in rats. Arch Pharm Res 30: 1426

Diopan V, Babula P, Shestivska V, Adam V, Zemlicka M, Dvorska M, Hubalek J, Trnkova L, Havel L, Kizek R 2008: Electrochemical and spectrometric study of antioxidant activity of pomiferin, isopomiferin, osajin and catalposide. J Pharm Biomed Anal 48: 127-133

Florian T, Necas J, Bartosikova L, Klusakova J, Suchy V, El Naggar BE, Janostikova E, Bartosik T 2006: Effects of prenylated isoflavones osajin and pomiferin in premedication on heart ischemia-reperfusion. Biomed Pap Med Fac Univ Palacky Olomouc Czech Repub 150: 93-100

Halici M, Kufrevioglu OI, Odabasoglu F, Halici Z, Cakir A, Aslan A 2011: The ethanol-water extract of Ramalina capitata has gastroprotective and antioxidative properties: an experimental study in rats with indomethacininduced gastric injuries. J Food Biochem 35: 11-26

Halici M, Odabasoglu F, Suleyman H, Cakir A, Aslan A, Bayir Y 2005: Effects of water extract of Usnea longissima on antioxidant enzyme activity and mucosal damage caused by indomethacin in rats. Phytomedicine 12: $656-662$

Jia Y-T, Ma B, Wei W, Xu Y, Wang Y, Tang H-T, Xia Z-F 2007: Sustained activation of nuclear factor-kB by reactive oxygen species is involved in the pathogenesis of stress-induced gastric damage in rats. Crit Care Med 35: $1582-1591$

Kaplan KA, Odabasoglu F, Halici Z, Halici M, Cadirci E, Atalay F, Aydin O, Cakir A 2012: Alpha-lipoic acid protects against indomethacin-induced gastric oxidative toxicity by modulating antioxidant system. J Food Sci 77: $\mathrm{H} 224-\mathrm{H} 230$

Kim J-E, Heo Y-S, Lee KW 2017: Osajin inhibits solar UV-induced cyclooxygenase-2 expression through direct inhibition of RSK2. J Cell Biochem 118: 4080-4087

Laine L 2016: Upper gastrointestinal bleeding due to a peptic ulcer. New Engl J Med 374: 2367-2376

Matsui H, Shimokawa O, Kaneko T, Nagano Y, Rai K, Hyodo I 2011: The pathophysiology of non-steroidal anti-inflammatory drug (NSAID)-induced mucosal injuries in stomach and small intestine. J Clin Biochem Nutr 48: 107-111

Morsy MA, Ashour OM, Fouad AA, Abdel-Gaber SA 2010: Gastroprotective effects of the insulin sensitizers rosiglitazone and metformin against indomethacin-induced gastric ulcers in Type 2 diabetic rats. Clin Exp Pharmacol Physiol 37: 173-177

Musumba C, Pritchard D, Pirmohamed M 2009: Cellular and molecular mechanisms of NSAID-induced peptic ulcers. Aliment Pharmacol Ther 30: 517-531

Odabasoglu F, Cakir A, Suleyman H, Aslan A, Bayir Y, Halici M, Kazaz C 2006: Gastroprotective and antioxidant effects of usnic acid on indomethacin-induced gastric ulcer in rats. J Ethnopharmacol 103: 59-65

Odabasoglu F, Halici Z, Cakir A, Halici M, Aygun H, Suleyman H, Cadirci E, Atalay F 2008: Beneficial effects of vegetable oils (corn, olive and sunflower oils) and $\alpha$-tocopherol on anti-inflammatory and gastrointestinal profiles of indomethacin in rats. Eur J Pharmacol 591: 300-306

Ohkawa H, Ohishi N, Yagi K 1979: Assay for lipid peroxides in animal tissues by thiobarbituric acid reaction. Anal Biochem 95: 351-358

Pandır D, Per S, Doğanyiğit Z, Bekdemir FO, Gök G, Demirbağ A 2019: All aspects of the toxic effects of lipopolysaccharide on rat liver and the protective effect of vitamin E and sodium selenite. Turk J Zool 43: 566-579

Rainsford KD 1988: Gastrointestinal damage from nonsteroidal anti-inflammatory drugs. Toxicol Pathol 16: 251-259

Sedlak J, Lindsay RH 1968: Estimation of total, protein-bound, and nonprotein sulfhydryl groups in tissue with Ellman's reagent. Anal Biochem 25: 192-205

Sivalingam N, Basivireddy J, Balasubramanian KA, Jacob M 2008: Curcumin attenuates indomethacin-induced oxidative stress and mitochondrial dysfunction. Arch Toxicol 82: 471-481

Slater T, Cheeseman K, Davies M, Proudfoot K, Xin W 1987: Free radical mechanisms in relation to tissue injury. Proc Nutr Soc 46: 1-12

Sun Y, Oberley LW, Li Y 1988: A simple method for clinical assay of superoxide dismutase. Clin Chem 34: 497-500

Wang T, Zhao S, Wang Y, Yang Y, Yao L, Chu L, Du H, Fu F 2014: Protective effects of escin against indomethacininduced gastric ulcer in mice. Toxicol Mech Methods 24: 560-566 
Plate VI

Erol H. S. et al.: Anti-ulcerogenie ... pp. 391-400

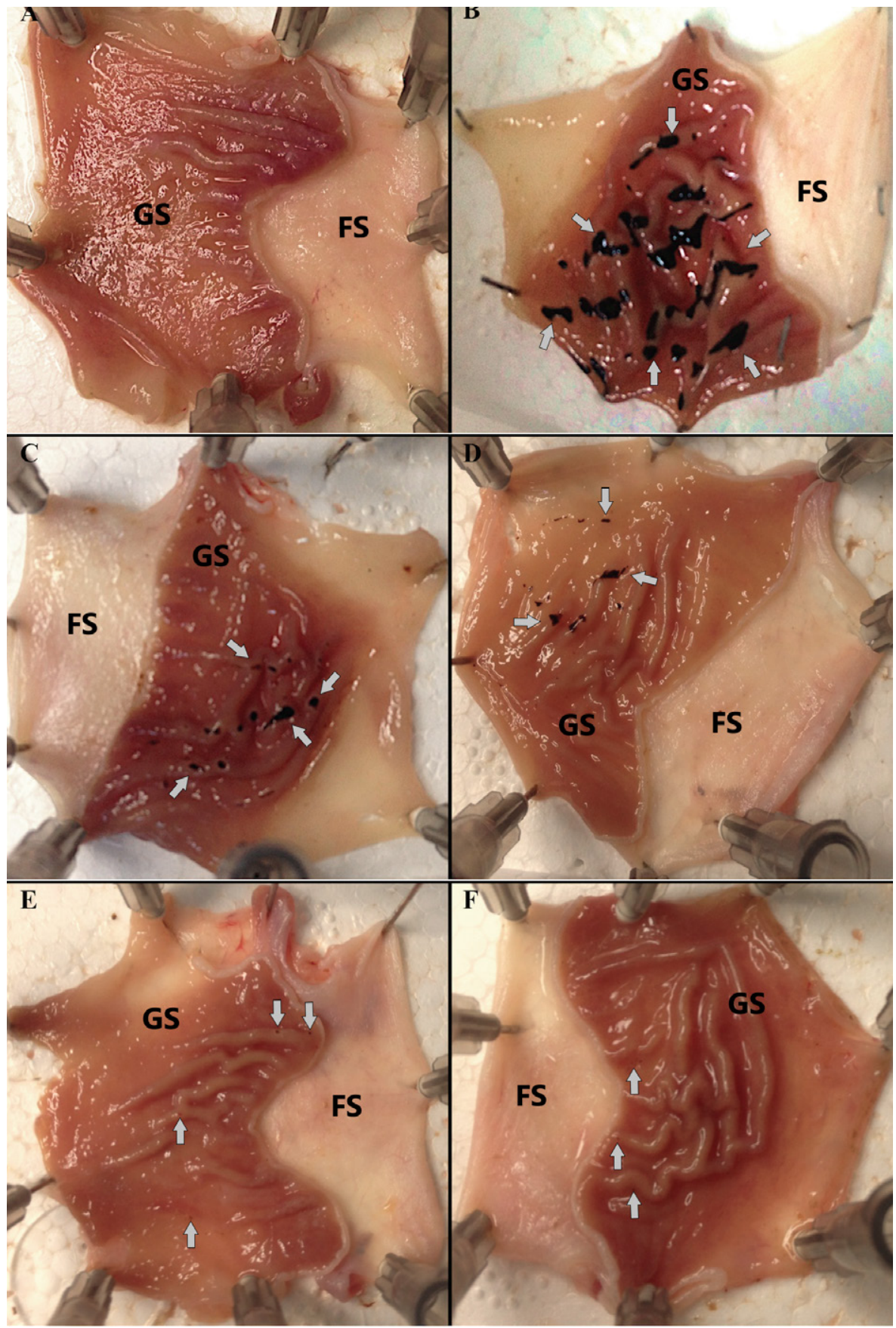

Fig. 2. The macroscopic view of rat stomachs. A: healthy control group; B: IND group; C: RAN group; D: OSJ 100 group; E: OSJ 200 group; F: OSJ 400 group.

IND - indomethacin, RAN - ranitidine, OSJ - osajin, GS - glandular stomach, FS - forestomach 

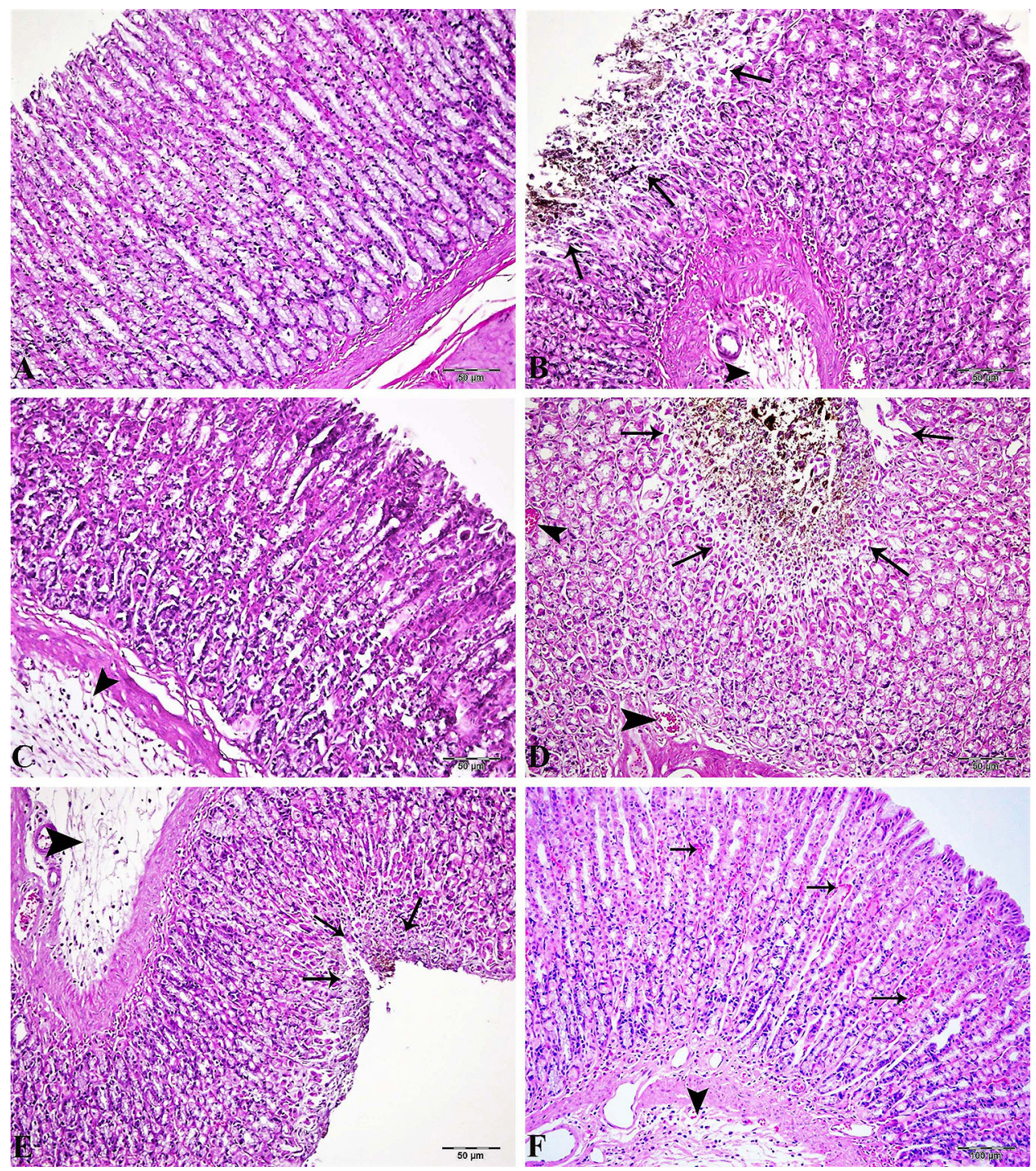

Fig. 4. Histopathological views of stomach tissues. A: healthy control group, normal histological view, haematoxylin and eosin, bar: $50 \mu \mathrm{m}$; B: IND group, severe necrotic haemorrhagic gastritis (arrows) in mucosa, mononuclear cell infiltration, oedema in submucosa (arrowheads), haematoxylin and eosin, bar: $50 \mu \mathrm{m} ; \mathrm{C}$ : RAN group, slight necrosis in mucosa epithelium (arrowhead), haematoxylin and eosin, bar: $50 \mu \mathrm{m}$; D: OSJ 100 group, severe necrotic haemorrhagic gastritis in mucosa (arrows), hyperaemia in vessels (arrowheads), haematoxylin and eosin, bar: $50 \mu \mathrm{m}$; E: OSJ 200 group, mild haemorrhage in the mucosa epithelium and necrosis (arrows), mild oedema in the submucosa (arrow heads), haematoxylin and eosin, bar: $50 \mu \mathrm{m}$; F: OSJ 400 group, slight necrosis in the mucosa epithelium and hyperaemia in vessels (arrows), slight oedema in the submucosa (arrowhead), haematoxylin and eosin, bar: $100 \mu \mathrm{m}$.

IND - indomethacin, RAN - ranitidine, OSJ - osajin 